\title{
COMPARISON STUDY BETWEEN LIME APPLICATION METHODS ON HMA ASPHALT CONCRETE IN IRAQ
}

\author{
Amjad H. K. Albayati, Assist prof. Transportation. Engineering, University of Baghdad, \\ Sirtransportation@yahoo.com \\ Ahmed M. M. Alani, M.Sc Candidate Transportation Engineering, University of Baghdad
}

doi: 10.2478/ijpeat-2013-0002

\section{ABSTRACT}

Iraq has been experiencing tremendous development in the national infrastructure road network over the last decade. Iraqi economic growth in rural areas has been triggered by good and safe roads and a good highways network system. Studies have shown that climate, traffic conditions, characteristics of the asphalt binder and the aggregate are the main factors that can contribute to premature pavement failures. The ability of hydrated lime to improve the fatigue and rutting resistance of Hot Mix Asphalt (HMA) as well as moisture sensitivity, has led to observed improvement in the field of lime modified HMA pavements, and significant decreases in maintenance and repair costs of the highway network. In this study, the mechanistic properties of asphalt concrete mixes modified with hydrated lime as a partial replacement for limestone dust mineral filler were evaluated. Four replacement rates were used; 1, 1.5, 2, and 3 percent by weight of aggregate beside two kinds of addition methods, namely dry and wet. Asphalt concrete mixes were prepared at their optimum asphalt content and then tested to evaluate their engineering properties which include moisture damage, resilient modulus, and permanent deformation and fatigue characteristics. These properties have been evaluated using indirect tensile strength, uniaxial repeated loading and repeated flexural beam tests. The experimental results, in general, showed that the mixes modified with hydrated lime were found to have improved fatigue and permanent deformation characteristics, also showing lower moisture susceptibility and higher resilient modulus. The use of 1.5 percent of hydrated lime in the wet addition method as a replacement for limestone dust mineral filler has shown a significant improvement in asphalt concrete behavior and has added to the local knowledge the possibility of producing more durable mixtures with higher resistance to distress.

\section{BACKGROUND}

The related mechanisms and reactions involved in the change of the performance of limemodified HMA mixtures are not totally understood. Nevertheless, when hydrated lime is added to HMA, a portion of the lime forms insoluble salts with the highly polar molecules of the asphalt, which could otherwise react in the mix to form water-soluble soaps that promote stripping (National Lime Association 2003). Dispersion of the tiny 
hydrated lime particles throughout the mix makes it stiffer and tougher, reducing the likelihood that the bond between the bitumen binder and the aggregate will be broken mechanically. Furthermore, a portion of the hydrated lime can reduce the viscositybuilding polar components in the asphalt binder and thus improve the long-term oxidative aging characteristics of HMA (Huang et al. 2002). The structure of hydrated lime consists of differently sized proportions. The smaller fraction of lime increases binder film thickness, enhances binder viscosity, and improves binder cohesion leading to increased adhesion between the aggregates and binder, which reduces mixture segregation (Mohammad et al 2000). The larger fraction performs as filler and increases the indirect tensile strength and resilient modulus as well as improving (i.e., decreasing) both the indirect tensile creep slope and the fatigue slope (with higher number of cycles to failure of HMA) (Kennedy and Ping 1991; Mohammad et al 2000; Sebaaly 2006). It has also been reported that the addition of lime to HMA improves its resistance to rutting (Little and Epps 2001; AlSuhaibani 1992; Shahrour and Saloukeh 1992). Hydrated lime replacement for limestone or baghouse dust has gained a considerable recognition due to its efficient effects on both pavement performance and cost, manifesting its benefits in decreasing maintenance and repair in current and newly constructed pavement sections. (Sebaaly et al. 2003) conducted research to quantify the improvements of pavement performance with the inclusion of lime. Performances of HMA mixtures from the northwestern part of Nevada were evaluated both in the laboratory and in the field. In the laboratory evaluation, both lime treated and untreated sections were sampled and then evaluated through laboratory tests. On the other hand, pavement performance data from a pavement management system (PMS) were used to assess field performance of lime treated and untreated sections. The study showed that lime treatment on HMA mixtures significantly improved their moisture resistance and resistance to multiple freeze-thaw cycles compared to untreated HMA mixtures. From the long-term pavement performance data it was also evident that under similar environmental and traffic conditions, lime treated mixtures provided better performance with less maintenance and rehabilitation activities. Again, the analysis of the impact of lime on pavement life indicated that lime treatment extended the performance life of HMA pavements by an average of 3 years which represented an average increase of $38 \%$ in the expected pavement life. Various ways to add hydrated lime, i.e., into the drum, as mixed filler, dry to the damp aggregate, as lime slurry, with or without marination could be implemented. No definitive evidence demonstrates that one method is more effective than the other. In general, contractors and (or) transportation departments have adopted one or more of three popular techniques, in dry, wet, and slurry states. The three techniques along with a brief description of each one are listed in Figure 1 (Button and Epps 1983).

\begin{tabular}{|c|c|c|c|}
\hline Method & Description & Major positives & Major negatives \\
\hline \multirow{2}{*}{ Dry } & Simplest method & Least expensive & Dusting and lime loss \\
\hline & $\begin{array}{l}\text { Lime and mineral filler introduced just } \\
\text { after introduction of asphalt }\end{array}$ & $\begin{array}{l}\text { Direct contact between aggregates and } \\
\text { lime } \\
\text { Lime and mineral filler introduced just } \\
\text { after introduction of asphalt }\end{array}$ & $\begin{array}{l}\text { Minimal mixing and coating of } \\
\text { aggregates }\end{array}$ \\
\hline \multirow[t]{5}{*}{ Wet } & $\begin{array}{l}\text { Lime metered into aggregate at a } \\
\text { moisture content of } 2 \%-3 \% \text { higher } \\
\text { than SSD condition }\end{array}$ & Proper coverage and application & $\begin{array}{l}\text { Expensive due to extra fuel needed to } \\
\text { dry aggregates before mix production }\end{array}$ \\
\hline & $\begin{array}{l}\text { Mixture processed in pug mill to ensure } \\
\text { thorough mixing }\end{array}$ & $\begin{array}{l}\text { Portion not mixing with aggregate will } \\
\text { mix with asphalt thus still aiding as } \\
\text { anti-stripping agent and antioxidant }\end{array}$ & - \\
\hline & $\begin{array}{l}\text { Aggregates kept in moist condition to } \\
\text { marinate for up to } 48 \mathrm{~h}\end{array}$ & $\begin{array}{l}\text { Moisture content slowly reduced over } \\
\text { stockpiling period }\end{array}$ & Aggregate handling effort increased \\
\hline & - & - & Storage space for aggregate stockpiling \\
\hline & - & $\begin{array}{l}\text { Stockpiling can be separated from pro- } \\
\text { duction thus providing an economic } \\
\text { advantage }\end{array}$ & $\begin{array}{l}\text { Concerns over carbonation with long } \\
\text { stockpiling times }\end{array}$ \\
\hline \multirow[t]{2}{*}{ Slurry } & $\begin{array}{l}\text { Slurry of lime and water applied to ag- } \\
\text { gregates }\end{array}$ & Improved coverage of aggregates & Increased water and fuel costs \\
\hline & Marination optional & $\begin{array}{l}\text { Reduced dispersion and loss of lime } \\
\text { Improved stripping protection }\end{array}$ & $\begin{array}{l}\text { Expensive, specialized equipment } \\
\text { requirements }\end{array}$ \\
\hline
\end{tabular}




\section{MATERIAL CHARACTERIZATION}

The materials used in this work, namely asphalt cement, aggregate, and fillers were characterized using routine types of test and results were compared with state corporation for roads and bridges specifications (SCRB, R/9 2003).

\section{Asphalt cement}

The asphalt cement used in this work is of 40-50 penetration grade. It was obtained from the Dora refinery, south-west of Baghdad. The asphalt properties are shown in Table (1) below.

\section{Table 1. Properties of asphalt cement}

\begin{tabular}{|c|c|c|c|}
\hline \multirow[t]{2}{*}{ Property } & \multirow[t]{2}{*}{ ASTM designation } & \multicolumn{2}{|c|}{$\begin{array}{c}\text { Penetration grade } \\
40-50\end{array}$} \\
\hline & & Test results & $\begin{array}{c}\text { SCRB } \\
\text { specification }\end{array}$ \\
\hline 1-Penetration at $25 \mathrm{C}, 100 \mathrm{gm}, 5 \mathrm{sec}$ ( $(0.1 \mathrm{~mm})$ & D-5 & 45 & $40-50$ \\
\hline 2- Rotational viscosity at $135^{\circ} \mathrm{C}$ (cP.s) & D4402 & 523 & ...... \\
\hline 2- Softening Point. $\left({ }^{\circ} \mathrm{C}\right)$ & D-36 & 49 & ...... \\
\hline 3-Ductility at $25 \mathrm{C}, 5 \mathrm{~cm} / \mathrm{min},(\mathrm{cm})$ & D-113 & $>100$ & $>100$ \\
\hline 4-Flash Point, $\left({ }^{\circ} \mathrm{C}\right)$ & D-92 & 290 & Min.232 \\
\hline 5-Specific Gravity & D-70 & 1.041 & ...... \\
\hline 6- Residue from thin film oven test & D-1754 & & \\
\hline - Retained penetration, $\%$ of original & D-5 & 59.5 & $>55$ \\
\hline - Ductility at $25 \mathrm{C}, 5 \mathrm{~cm} / \mathrm{min},(\mathrm{cm})$ & D-113 & 80 & $>25$ \\
\hline
\end{tabular}

\section{Aggregate}

The aggregate used in this work was crushed quartz obtained from Amanat Baghdad bituminous concrete mix plant located in Taji, north of Baghdad; its source is Al-Nibaie quarry. This aggregate is widely used in Baghdad city for asphaltic mixes. The coarse and fine aggregates used in this work were sieved and recombined in the proper proportions to meet the wearing course gradation as required by SCRB specification (SCRB, R/9 2003). The gradation curve for the aggregate is shown in Figure (2). Routine tests were 
performed on the aggregate to evaluate their physical properties. The results together with the specification limits as set by the SCRB are summarized in Table (2). Tests results show that the chosen aggregate met the SCRB specifications.

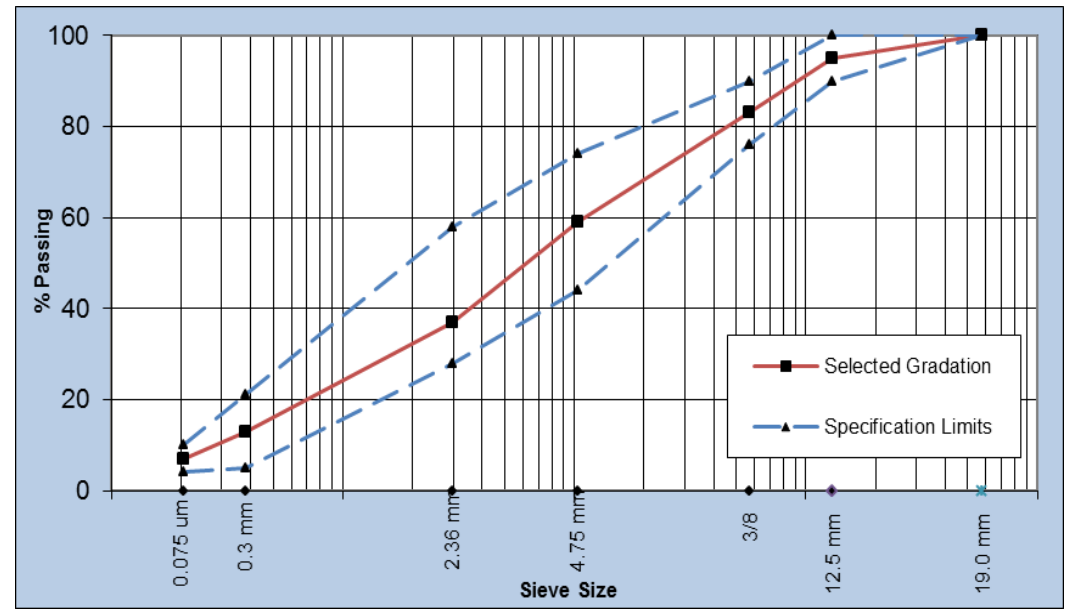

Figure 2. Aggregate gradation

Table 2. Physical properties of aggregates

\begin{tabular}{|c|c|c|c|}
\hline Property & ASTM designation & Test results & $\begin{array}{c}\text { SCRB } \\
\text { specification }\end{array}$ \\
\hline \multicolumn{4}{|l|}{ Coarse aggregate } \\
\hline 1. Bulk specific gravity & C-127 & 2.614 & ...... \\
\hline 2. Apparent specific gravity & & 2.686 & ...... \\
\hline 3. Water absorption, $\%$ & & 0.441 & ...... \\
\hline 4. Percent wear by Los Angeles abrasion & & & \\
\hline 5. $\%$ & C-131 & 17.5 & 30 Max \\
\hline solution, $\%$ & C-88 & 3.4 & 12 Max \\
\hline 6. Fractured pieces, $\%$ & & 98 & 90 Min \\
\hline \multicolumn{4}{|l|}{ Fine aggregate } \\
\hline 1. Bulk specific gravity & C-127 & 2.664 & ...... \\
\hline 2. Apparent specific gravity & & 2.696 & ...... \\
\hline 3. Water absorption, $\%$ & & 0.724 & ...... \\
\hline 4. Sand equivalent, $\%$ & D-2419 & 57 & 45 Min. \\
\hline
\end{tabular}

\section{Filler}

The filler is a non-plastic material passing sieve No.200 $(0.075 \mathrm{~mm})$. In this work, the control mixes were prepared using limestone dust as mineral filler at a content of 7 percent, this content representing the mid-range set by the SCRB specification for the type IIIA mixes of wearing course. Mixes in which the limestone dust was partially replaced by a hydrated lime were also prepared. The replacement percentages were 1.0, $1.5,2$, and $3 \%$ by total weight of aggregate. The limestone dust and hydrated lime were obtained from a lime factory in Karbala governorate, south east of Baghdad. The chemical composition and physical properties of the fillers are presented in Table (3) below: 


\section{Table 3. Properties of fillers}

\begin{tabular}{|c|c|c|c|c|c|c|c|c|c|c|}
\hline \multirow{2}{*}{$\begin{array}{r}\text { Filler } \\
\text { type }\end{array}$} & \multicolumn{7}{|c|}{ Chemical Composition ,\% } & \multicolumn{3}{|c|}{ Physical Properties } \\
\hline & $\mathrm{CaO}$ & $\mathrm{SiO}_{2}$ & $\overline{\mathbf{A l}_{2} \mathbf{O}_{3}}$ & MgO & $\overline{\mathrm{Fe}_{2} \mathrm{O}_{3}}$ & $\overline{\mathrm{SO}_{3}}$ & L.O.I & $\begin{array}{l}\text { Specific } \\
\text { gravity }\end{array}$ & $\begin{array}{c}\text { Surface } \\
\text { area* } \\
\left(\mathrm{m}^{2} / \mathrm{kg}\right)\end{array}$ & $\begin{array}{c}\text { \% Passing } \\
\text { sieve No. 200( } \\
\text { 0.075) }\end{array}$ \\
\hline $\begin{array}{r}\text { Limestone } \\
\text { Dust }\end{array}$ & 68.3 & 2.23 & - & 0.32 & - & 1.20 & 27.3 & 2.41 & 244 & 94 \\
\hline $\begin{array}{r}\text { Hydrated } \\
\text { Lime }\end{array}$ & 56.1 & 1.38 & 0.72 & 0.13 & 0.12 & 0.21 & 40.6 & 2.78 & 398 & 98 \\
\hline
\end{tabular}

* Blain air permeability method (ASTM C204)

\section{EXPERIMENTAL WORK}

\section{Lime addition techniques and specimen fabrication}

In this study two methods were used in applying the hydrated lime into the aggregate. The dry lime was applied directly, heated and mixed with aggregate prior to asphalt introduction and this seems to be the simplest method for lime application technique and is called in this study the dry method. Meanwhile in the wet method dry aggregate blends were moisturized with an addition of $3.0 \%$ water by weight of total aggregates; dry hydrated lime at a different rate by total dry weight of aggregate was then mixed with the wet aggregates for 10 minutes to produce evenly distributed lime-water films on the aggregate surfaces. The lime-treated aggregates were then oven dried for four hours to eliminate all water prior to the addition of the asphalt binder. Each mixture was designed with the same blend of aggregates in order to keep aggregate angularities and mineralogical characteristics constant. The only variable in the mixtures was the replacement rates of hydrated lime $(1.0,1.5,2.0$, and 3\%). Consequently, in order to determine the optimum percent of asphalt cement in bituminous concrete mixtures, a triplicate number of specimens for each asphalt content by Marshall Mix design method (ASTM D6926-2010a) were prepared. Nine mixes were prepared for this purpose, four mixes using the dry method, four mixes using the wet method and one as a control mix with zero hydrated lime content. The Marshall Test results showed that $4.9 \%$ is the optimum percent for bituminous concrete mixtures. The specimens prepared for this study, had a diameter of $100 \mathrm{~mm}$ and height of $63 \mathrm{~mm}$ for Marshall and tensile strength ratio (ASTM- D-4867-96). Specimens were compacted using Marshall standard compaction procedures with 75 blows per face, except that for tensile strength the number of blows was less in order to produce HMA with targeted air voids between 68\%. A Superpave Gyratory Compactor (AASHTO 2004) was also used to fabricate HMA specimens with 50 gyrations of samples $101.1 \mathrm{~mm}$ in diameter and $203.3 \mathrm{~mm}$ in height to quantify the effect of hydrated lime on rutting potential. Also compacted beam specimens $76 \mathrm{~mm} \times 76 \mathrm{~mm} \times 381 \mathrm{~mm}$ were produced by means of static compaction using a "double plunger" arrangement, using a compressive machine, and pressed under the gradual application of a static load for 2 minutes according to (ASTM-D1074-96) to promote homogeneity; the mixture is generally "rodded" prior to compaction, and the mold is made "free floating" by using a "double plunger" arrangement. 


\section{Indirect tensile test}

The moisture susceptibility of the bituminous concrete mixtures was evaluated according to (ASTM- D-4867-96). The result of this test is the indirect tensile strength (ITS) and tensile strength ratio (TSR). In this test, a set of specimens was prepared for each mix according to Marshall Procedure and compacted to $7 \pm 1 \%$ air voids using different numbers of blows per face, varying from 34 to 49 (targeted air voids content were prepared to voids is not meant to mimic the actual field conditioning process but to accelerate the moisture damage in a manner that can be measured under laboratory conditions). The set consists of six specimens and was divided into two subsets, one set (control) was tested at $25^{\circ} \mathrm{C}$ and the other set (soaked) was subjected to one cycle of freezing and thawing then tested at $25^{\circ} \mathrm{C}$. The test is shown below in Figure 3. It involved loading the specimens with compressive load at a rate of $50.8 \mathrm{~mm} / \mathrm{min}$ acting parallel to and along the vertical diametral plane through $0.5 \mathrm{in}$. wide steel strips which are curved at the interface with the specimens. These specimens failed by splitting along the vertical diameter. The indirect tensile strength calculated according to (Eq.1) of the soaked specimens $\left(\mathrm{ITS}_{\mathrm{c}}\right)$ is divided by that of the control specimens $\left(\operatorname{ITS}_{\mathrm{d}}\right)$, which gives the tensile strength ratio (TSR) as the following (Eq.2).

$$
\begin{aligned}
& I T S=\frac{2 P}{\pi t D} \\
& T S R=\frac{I T S_{c}}{I T S_{d}}
\end{aligned}
$$

Where

ITS= Indirect tensile strength

$\mathrm{P}=$ Ultimate applied load

$\mathrm{t}=$ Thickness of specimen

$\mathrm{D}=$ Diameter of specimen

Other parameters are defined previously

\section{Uniaxial repeated loading test}

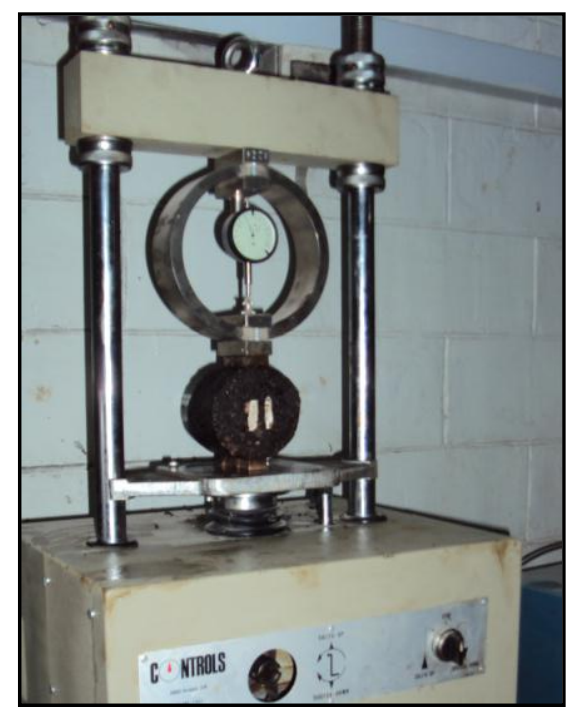

Figure 3. Photograph for ITS test

The uniaxial repeated loading tests were conducted on cylindrical specimens, $101.6 \mathrm{~mm}$ in diameter and $203.2 \mathrm{~mm}$ in height, using the pneumatic repeated load system (PRLS Albayati 2006) shown below in Figure 4. In these tests, repetitive compressive loading with a stress level of 20 psi was applied in the form of a rectangular wave with a constant loading frequency of $1 \mathrm{~Hz}(0.1 \mathrm{sec}$. load duration and $0.9 \mathrm{sec}$. rest period) and the axial permanent deformation was measured under the different loading repetitions. All the uniaxial repeated loading tests were conducted at $20^{\circ} \mathrm{C}, 40^{\circ} \mathrm{C}$ and $60^{\circ} \mathrm{C}$. The permanent strain ( $\varepsilon p)$ is calculated by applying the following equation:

$$
\varepsilon_{p}=\frac{p_{d} \times 10^{6}}{h} \quad \ldots . . \text { Eq. } 3
$$


Where

$\varepsilon p=$ axial permanent microstrain

$\mathrm{pd}=$ axial permanent deformation

$\mathrm{h}=$ specimen height

Also, during this test the resilient deflection was measured at load repetitions 50 to 100 , and the resilient strain ( $\mathrm{\varepsilon r}$ ) and resilient modulus (Mr) were calculated as follows (Huang 2004):

$$
\begin{aligned}
& \varepsilon_{r}=\frac{r_{d} \times 10^{6}}{h} \ldots . . \text { Eq. } 4 \\
& M_{r}=\frac{\sigma}{\varepsilon_{r}} \quad \ldots . . \text { Eq. } 5
\end{aligned}
$$

Where

$\varepsilon r=$ axial resilient microstrain

$\mathrm{rd}=$ axial resilient deflection

$\mathrm{h}=$ specimen height

$\mathrm{Mr}=$ Resilient modulus

$\sigma=$ repeated axial stress

$\varepsilon r=$ axial resilient strain

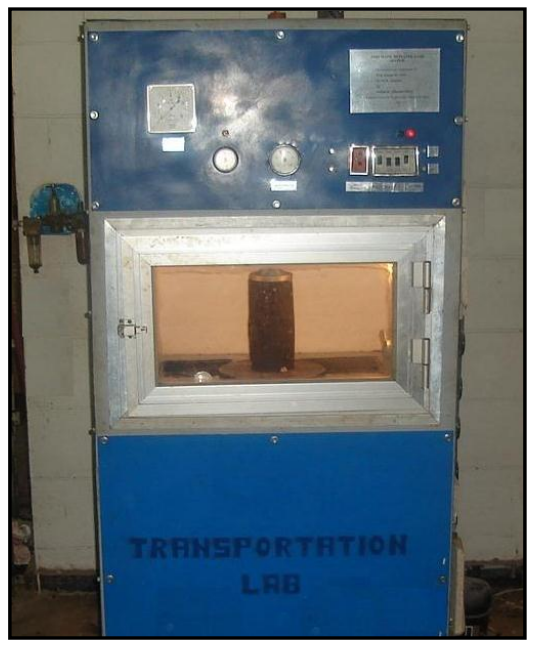

Figure 4. Photograph for the PRLS

The permanent deformation test results for this study are represented by a linear log-log relationship between the number of load repetitions and the permanent microstrain with the form shown in Eq.6 below which was originally suggested by Monismith et. al., (1975) and Barksdale (1971).

$$
\varepsilon_{p}=a N^{b} \ldots \ldots . \text { Eq. } 6
$$

Where

$\varepsilon_{\mathrm{p}}=$ permanent strain

$\mathrm{N}=$ number of stress applications

$\mathrm{a}=$ intercept coefficient

$\mathrm{b}=$ slope coefficient

\section{Flexural beam fatigue test}

Within this study, a third-point flexural fatigue bending test was adopted to evaluate the fatigue performance of bituminous concrete mixtures using the pneumatic repeated load system, this test was performed in stress controlled mode with flexural stress level varying from 5 to 30 percent of ultimate indirect tensile strength applied at a frequency of $2 \mathrm{~Hz}$ with $0.1 \mathrm{~s}$ loading and $0.4 \mathrm{~s}$ unloading times and in rectangular waveform shape. All tests were conducted as specified in SHRP standards at $20^{\circ} \mathrm{C}$ on beam specimens. In the fatigue test, the initial tensile strain of each test has been determined at the $50^{\text {th }}$ repetition by using (Eq.7) shown below and the initial strain was plotted versus the number of 
repetitions to failure on log scales, collapse of the beam being defined as failure, and the plot can be approximated by a straight line and has the form shown below in (Eq. 8).

$$
\begin{gathered}
\varepsilon_{t}=\frac{\sigma}{E s}=\frac{12 h \Delta}{3 L^{2}-4 a^{2}} \ldots . . \text { Eq. } 7 \\
N_{f}=k_{1}\left(\varepsilon_{t}\right)^{-k 2} \quad \ldots . . \text { Eq. } 8
\end{gathered}
$$

Where

$\varepsilon_{t}=$ Initial tensile strain

$\sigma=$ Extreme flexural stress

Es $=$ Stiffness modulus based on center deflection.

$\mathrm{h}=$ Height of the beam

$\Delta=$ Dynamic deflection at the center of the beam.

$\mathrm{L}=$ Length of span between supports.

$\mathrm{a}=$ Distance from support to the load point $(\mathrm{L} / 3)$

$N_{f}=$ Number of repetitions to failure

$k_{1}$ = fatigue constant, value of $\mathrm{N}_{\mathrm{f}}$ when $\varepsilon_{t}=1$

$k_{2}=$ inverse slope of the straight line in the logarithmic relationship

\section{TEST RESULTS AND DISCUSSION}

\section{Effects of hydrated lime on moisture susceptibility}

Based on the data shown in Figure 5, it appears that both the hydrated lime content and addition method have influence on the moisture susceptibility of the bituminous concrete mixes. The figure clearly demonstrates that both hydrated lime addition methods contributed to an increase in TSR and the general observation shows that the wet method seems to be more effective than the dry method. TSR has gained a considerable increase, by $4.2 \%, 5.9 \%, 10.9 \%$ and $9 \%$ with the dry method with ascending amounts of lime replacement as compared to the control mix. Meanwhile, the acquired gains in TSR with the wet method were $3.4 \%, 6 \%, 18.8 \%$ and $19.8 \%$. These results confirm the role of hydrated lime as a superior anti striping agent. The improvement in TSR can be attributed to the improvement in the adhesion between aggregate and asphalt cement due to the presence of hydrated lime by interacting with carboxylic acids in the asphalt and forming insoluble salts that are readily adsorbed at the aggregate surface (Plancher et al. 1977; and Hicks 1991). Relating these phenomena to local Iraqi paving materials is discussed as follows; the aggregate used in this study was brought form Al-Nibaie quarry, which is Quartzite and classified as acidic aggregate and the improvement was shown in that altering the surface chemistry of acidic aggregate causes a basic coating, and develops a strong bond between aggregate and acidic asphalt binder. Such bonding developed between asphalt binder and aggregate results in mitigation of moisture damage in the 
asphalt mixtures. The effect of the wet method of hydrated lime replacement was significant and even more impressive; this could be explained by the fact that wet replacement of hydrated lime on 3\% SSD provides better coverage and allows for proper application as compared addition of dry hydrated lime to dry aggregate. These advantages are possible because moisture ionizes lime and helps to distribute it on the surface of the aggregate. Also visual inspection of tested specimens showed more broken aggregates on the split faces which reflect higher bonding strength of the binder.

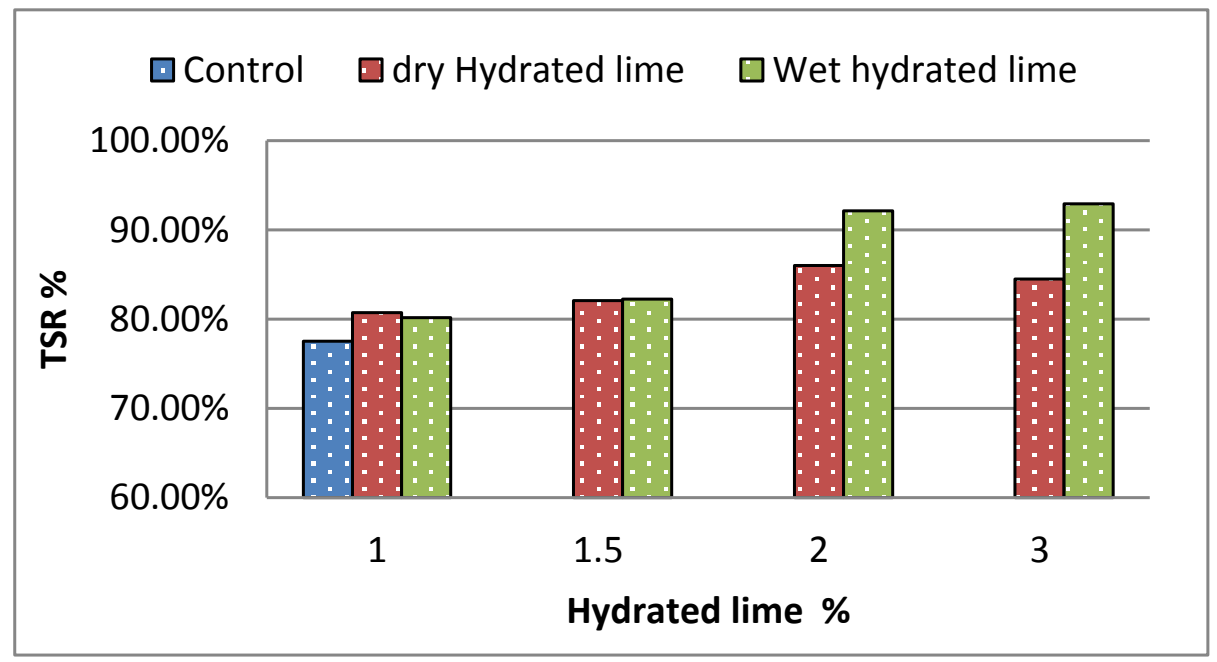

Figure 5. Effect of both methods on TSR\%

\section{Effects of hydrated lime on permanent deformation}

Permanent deformation manifests itself as a primary distress due to the hot climate of the Iraqi summer season. In this study the effect of hydrated lime has been quantified at a range of three testing temperatures $20^{\circ} \mathrm{C}, 40^{\circ} \mathrm{C}$ and $60^{\circ} \mathrm{C}$ representing the actual climate variation during the year in Iraq. Analysis of permanent deformation potential affected by the addition of hydrated lime is shown in figure 7 and 8 which is based on the data presented in Tables 5 and 6. Examination of the presented data suggests that the permanent deformation parameters (intercept and slope) are generally improved with the use of hydrated lime. At lower temperature $20^{\circ} \mathrm{C}$, the trend line of permanent deformation show a narrow corridor between control and lime treated mixture with different rates for both dry and wet hydrated lime methods. In other words, hydrated lime seems insignificant in reducing the slope and intercept values as shown in tables 5 and 6 This can be attributed to the fact that, hydrated lime had a minor effect at lower temperature in reducing the permanent deformation parameters and this was expected and indicated throughout the study of (Little and Petersen 2005). At intermediate and higher temperature, hydrated lime shows a significant effect in improving rutting resistance by decreasing the slope value. Using the dry method the slope value decreased as the amount of hydrated lime increased at $40^{\circ} \mathrm{C}$ and $60^{\circ} \mathrm{C}$; mixes replaced in the dry method with hydrated lime of $1.5 \%$ at $40^{\circ} \mathrm{C}$ and $60^{\circ} \mathrm{C}$ exhibit a lower slope value by $9.47 \%$ and $4.74 \%$ respectively. The addition more hydrated lime beyond this percentage may not represent the best scenario as the time to failure for the $3.0 \%$ case was not significantly different. 
The same scenario using the wet method is observed, the mixture with $2.0 \%$ exhibiting a lower slope value by $10.1 \%$ and $7.87 \%$ respectively at $40^{\circ} \mathrm{C}$ and $60^{\circ} \mathrm{C}$ compared to the control mix. As a summary from the test results it also appears that the addition of more than $1.5 \%$ hydrated lime for the dry method and $2.0 \%$ for the wet method did not improve the performance, as the time to failure for the $3.0 \%$ case was very similar to the time to failure of the $2.0 \%$ case, except at a lower temperature of $20^{\circ} \mathrm{C}$ where hydrated lime acts as inert filler and is less chemically active. The addition-reduction trend in permanent deformations of specimens of asphalt hydrated lime inclusion was more impressive. On the other hand, the wet method seems to be more effective in reducing the slope value. In general, hydrated lime shows a significant effect using both methods in HMA mixture as limestone dust replacement by increasing the resistance to permanent deformation. The results for both addition method and especially wet method confirm that the rutting mode of failure in bituminous concrete pavements which is enhanced can be reduced to a large extent with the introduction of hydrated lime to asphalt concrete mixtures during the hot summer season in Iraq.

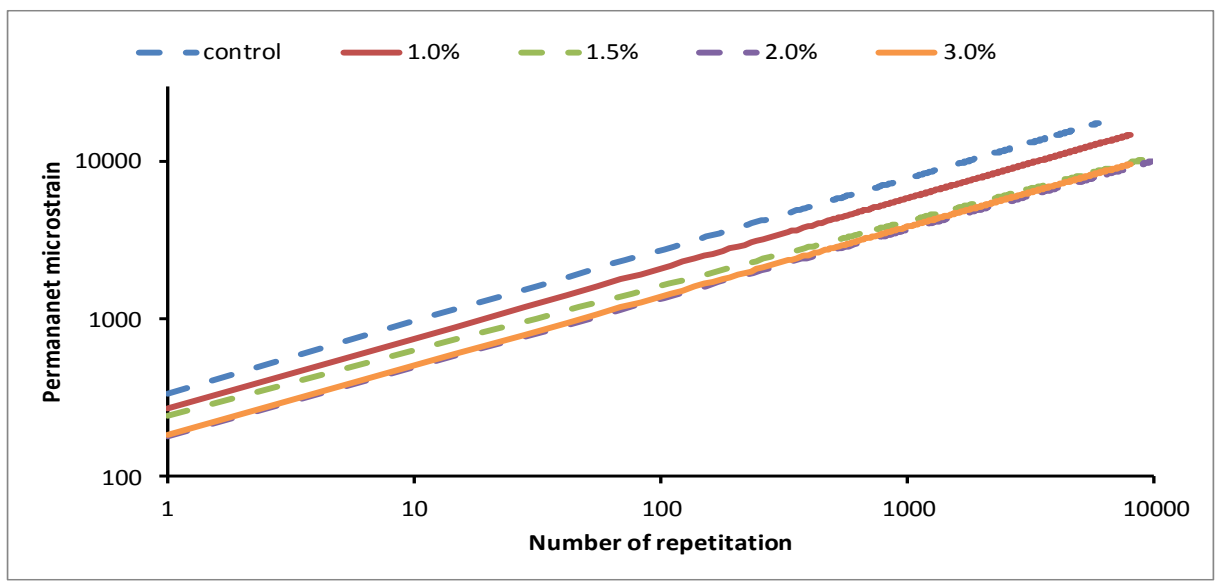

Figure 7. Effect of dry methods replacement on rutting resistance at $40^{\circ} \mathrm{C}$

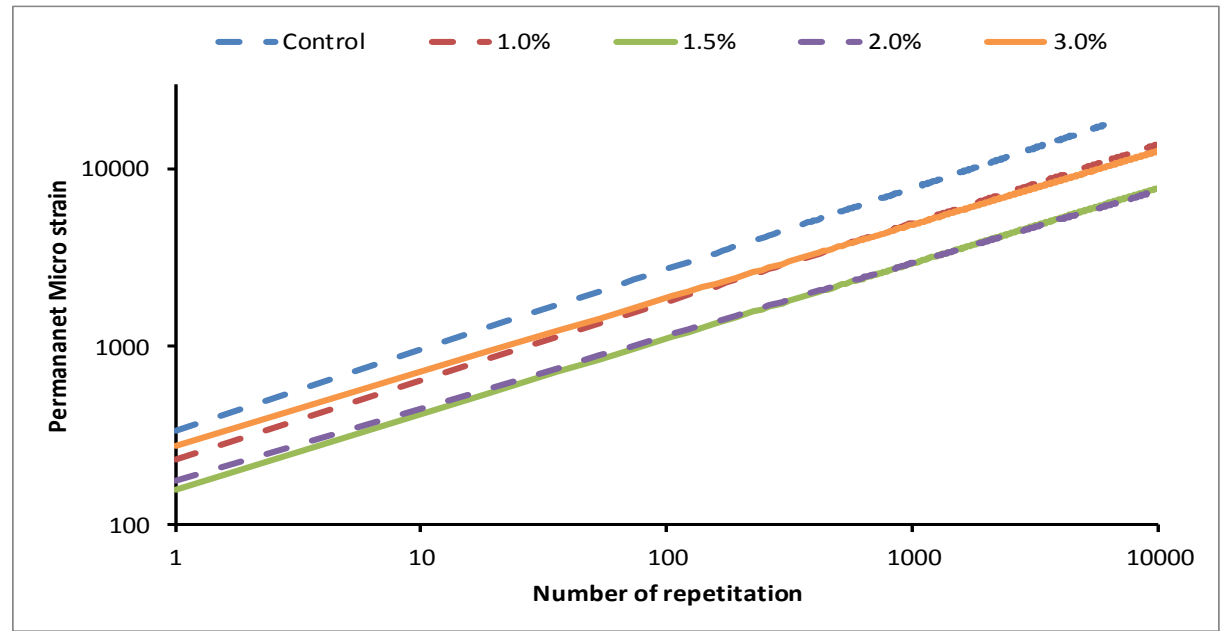

Figure 8. Effect of wet methods replacement on rutting resistance at $40^{\circ} \mathrm{C}$ Table 5. Intercept and slope coefficient for dry method 


\begin{tabular}{|c|c|c|c|c|c|c|}
\hline Mixture & \multicolumn{2}{|c|}{$20 \mathrm{C}^{0}$} & \multicolumn{2}{|c|}{$40 C^{0}$} & \multicolumn{2}{|c|}{$60 C^{0}$} \\
\hline Control & $\begin{array}{c}a \\
115.72\end{array}$ & $\begin{array}{c}b \\
0.2761\end{array}$ & $\begin{array}{c}\mathbf{a} \\
337.71\end{array}$ & $\begin{array}{c}b \\
0.454\end{array}$ & $\begin{array}{c}a \\
572.36\end{array}$ & $\begin{array}{c}b \\
0.5438\end{array}$ \\
\hline $1.0 \%$ & 110.32 & 0.2758 & 314.5 & 0.446 & $\mathbf{5 5 3 . 4 7}$ & 0.537 \\
\hline $1.5 \%$ & 106.57 & 0.2682 & 273.95 & 0.411 & 477.58 & 0.518 \\
\hline $2.0 \%$ & 95.071 & 0.2632 & 235.65 & 0.437 & 461.85 & 0.522 \\
\hline $3.0 \%$ & 72.659 & 0.2619 & 220.14 & 0.441 & 513.11 & 0.532 \\
\hline
\end{tabular}

Table (6) intercept and slope coefficient for wet method

\begin{tabular}{|c|c|c|c|c|c|c|}
\hline \multirow[t]{2}{*}{ Mixture } & \multicolumn{2}{|c|}{$20 \mathrm{C}^{0}$} & \multicolumn{2}{|c|}{$40 C^{0}$} & \multicolumn{2}{|c|}{$60 C^{0}$} \\
\hline & $\mathbf{a}$ & b & $\mathbf{a}$ & b & $\mathbf{a}$ & b \\
\hline $1.0 \%$ & 113.72 & 0.2722 & 271.98 & 0.442 & 535.16 & 0.528 \\
\hline $1.5 \%$ & 101.13 & 0.2681 & 257.73 & 0.423 & 488.64 & 0.511 \\
\hline $2.0 \%$ & 83.159 & 0.267 & 223.57 & 0.408 & 420.92 & 0.501 \\
\hline $3.0 \%$ & 68.633 & 0.2566 & 262.93 & 0.414 & 473.71 & 0.509 \\
\hline
\end{tabular}

\section{Effects of hydrated lime on resilient modulus}

Table 7 as well as Figure 9 exhibits the variation of the resilient modulus values with hydrated lime content as well as addition method. The general theme which can be abstracted from the figure reflects that as the percentage of hydrated lime is increased the resilient modulus increases for both types of addition method indicating that the mixes are becoming stiffer. Also for any specified hydrated lime content, the resilient modulus value is higher when the dry addition method is used as compared to the wet addition method and these differences in resilient modulus values are more pronounced at a low testing temperature of $20^{\circ} \mathrm{C}$ but tend to vanish at a high testing temperature of $60^{\circ} \mathrm{C}$. When 3 percent hydrated lime is used in bituminous concrete mixes, for $20^{\circ} \mathrm{C}, 40^{\circ} \mathrm{C}$ and $60^{\circ} \mathrm{C}$ testing temperature, the increment rates in resilient modulus values are 40.2, 35.2 and 25.4 percent with the dry addition method whereas for the wet addition method the corresponding values are 29.1, 23.8 and 10.8 percent as compared to the control mixture with 0 percent hydrated lime

Table (7) Effect of hydrated lime content and addition method On resilient modulus (Kpa)

\begin{tabular}{|c|c|c|c|c|c|c|}
\hline Mixture & $20 C^{0}$ & Gains \% & $40 C^{0}$ & Gains \% & $60 C^{0}$ & Gains \% \\
\hline Control & 1233833 & $\overline{0}$ & 791068 & $\overline{0}$ & 551110 & $\mathbf{0}$ \\
\hline $1.0 \%$ dry & 1537985 & 19.7 & 880225 & 10.1 & 606726 & 9.1 \\
\hline $1.5 \%$ dry & 1708182 & 27.7 & 1027429 & 23 & 640825 & 13.9 \\
\hline $2.0 \%$ dry & 1763557 & 30 & 1085801 & 27.1 & 674827 & 18.3 \\
\hline $3.0 \%$ dry & 2066669 & 40.2 & 1221307 & 35.2 & 739613 & 25.4 \\
\hline $1.0 \%$ wet & 1377779 & 10.4 & 870172 & 9.09 & 590473 & 6.66 \\
\hline $1.5 \%$ wet & 1469630 & 16.04 & 887934 & 10.9 & 607188 & 9.23 \\
\hline $2.0 \%$ wet & 1613011 & 23.5 & 966859 & 18.18 & 652979 & 15.6 \\
\hline $3.0 \%$ wet & 1740351 & 29.1 & 1038529 & 23.8 & 618067 & 10.8 \\
\hline
\end{tabular}

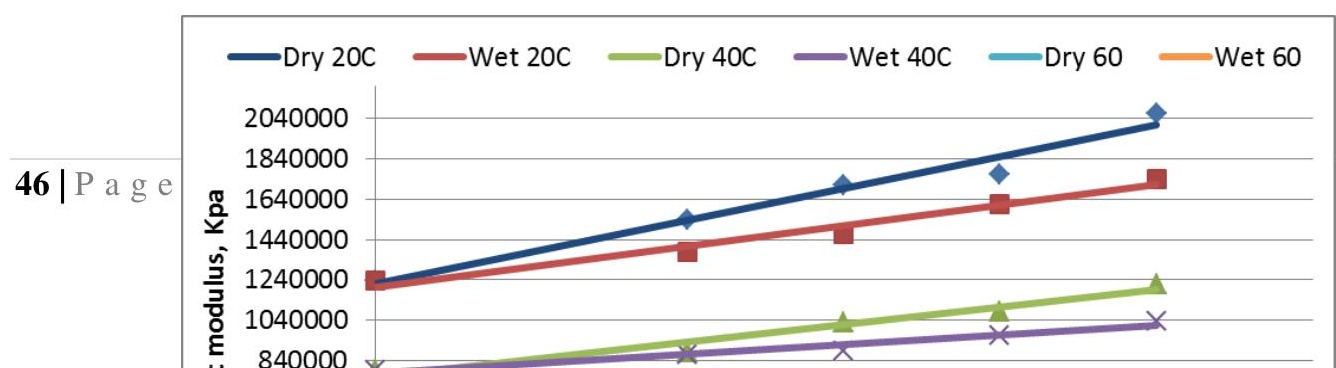


Figure 9. Effect of hydrated lime content and addition methods on resilient modulus

\section{Effects of hydrated lime on fatigue performance}

The fatigue characteristic curves for all mixtures are presented in Figure 10 and 11. The fatigue parameters $k_{1}$ and $k_{2}$ are shown in Table 7 and 8 . Values of $k_{1}$ and $k_{2}$ can be used as indicators of the effects of hydrated lime on the fatigue characteristics of a paving mixture. The flatter the slope of the fatigue curve, the larger the value of $k_{2}$. If two materials have the same $k_{1}$ value, then a large value of $k_{2}$ indicates a potential for longer fatigue life. On the other hand, a lower $k_{1}$ value represents a shorter fatigue life when the fatigue curves are parallel, that is, $k_{2}$ is constant.

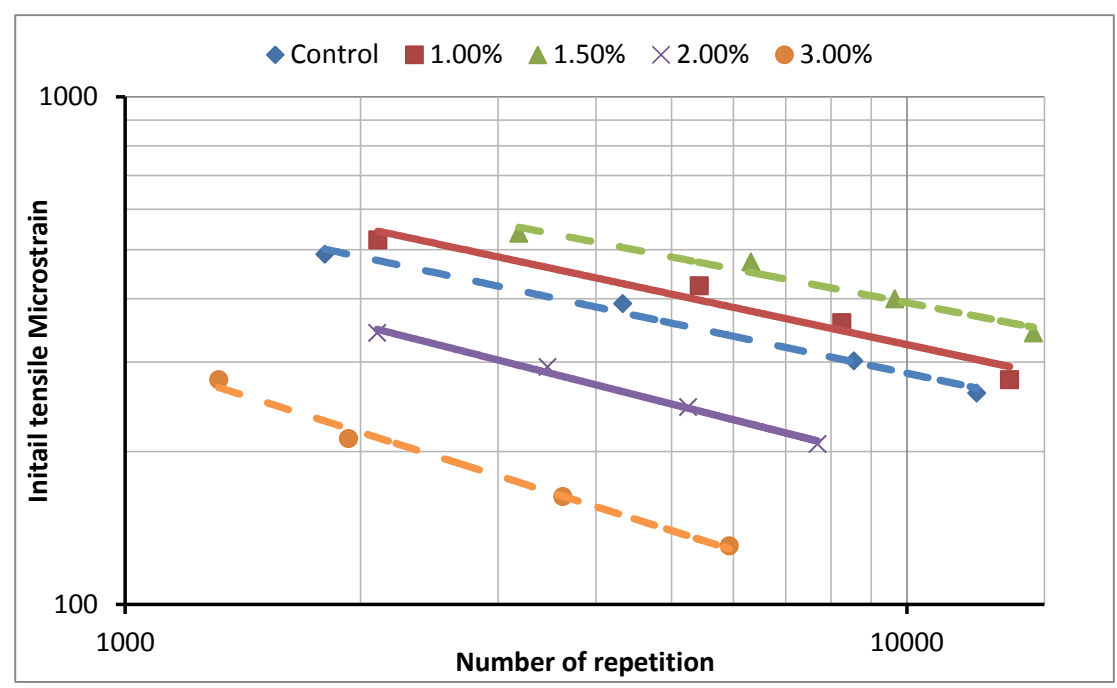

Figure 10. Hydrated lime replacement by dry method 


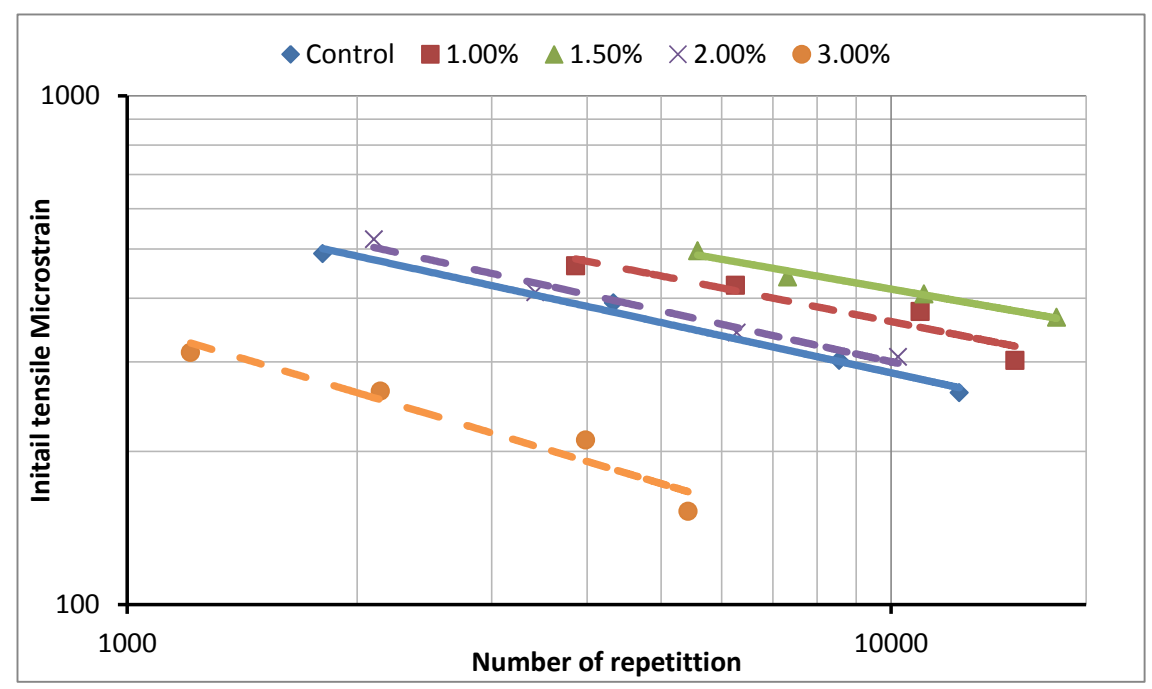

Figure 11. Hydrated lime replacement by wet method

From the figures above, it is clearly shown that the dry method with replacement rate of $1.0 \%$ and $1.5 \%$ shows higher fatigue resistance which is accompanied by increasing numbers of repetition and increased $\mathrm{K} 2$ as compared to control mix values by $10 \%$ and $17 \%$ respectively. However a drastic reduction happened when the dose increased beyond a threshold limit of $1.5 \%$ resulting in a decrease in $\mathrm{K} 2$ value by $8 \%$, and $26 \%$ for $2.0 \%$ and $3.0 \%$, respectively. It is worth noting here that all of the K1 values ranged between 4.13E-08 to 5.91E-05 using the dry method and the minimum K1 value was obtained when 1.5 percent hydrated lime was used. For the wet method, the general trend observed from Figures and tables shows a synergistic effect to the dry method by increasing the fatigue life to a point and then, with extra amounts, causing deterioration of fatigue resistance. Mixtures with $1.0 \%$ and $1.5 \%$ show higher fatigue resistance firstly by increasing in numbers of repetition to failure and secondly by increasing the $\mathrm{K} 2$ values which were 3.355 for the former and 3.787 for the latter with an increment of $17.4 \%$ and $26.8 \%$ as compared to the control mixture with 0 hydrated lime content. In comparing the effect of the two addition methods, the wet method extends the fatigue life better than the dry method for the same percentage of hydrated lime content. The overall result for the fatigue test showed that the mixture with 1.5 percent hydrated lime yielded the better results in both dry and wet methods, this is a clear indication of the positive effects of hydrated lime on fatigue damage resistance by its toughening mechanisms related to physicochemical interactions with binder and mineral aggregates. However, adding toughening can be impeded by adding a critical amount of hydrated lime which produces mixtures that are prone to cracking due to material brittleness which confirmed when comparing the average fatigue lives for number of repetition shown in Figure 12. 
Table 7. Fatigue life using dry methods

\begin{tabular}{cccccc} 
Mixture & Fatigue Equation & \multicolumn{3}{c}{ Number of repetition to fracture (Nf) for Each } \\
Stress Level
\end{tabular}

Table 8. Fatigue life using wet methods

\begin{tabular}{|c|c|c|c|c|c|}
\hline \multirow{2}{*}{$\begin{array}{c}\text { Mixture } \\
1.0 \%\end{array}$} & \multirow{2}{*}{$\begin{array}{c}\text { Fatigue Equation } \\
N_{\mathrm{f}}=\mathbf{2 . 7 6 5 9 E - 0 8 E t ^ { - 3 . 3 5 5 }}\end{array}$} & \multicolumn{4}{|c|}{$\begin{array}{l}\text { Number of repetition to fracture (Nf) for Each } \\
\text { Stress Level }\end{array}$} \\
\hline & & 14537 & 10921 & 6258 & 3865 \\
\hline $1.5 \%$ & $N_{f}=1.58962 E-09 \varepsilon t^{-3.787}$ & 16482 & 11051 & 7320 & 5582 \\
\hline $2.0 \%$ & $N_{f}=2.43846 E-07 \varepsilon t^{-3.012}$ & 10218 & 6279 & 3421 & 2103 \\
\hline $3.0 \%$ & $N_{f}=2.08194 E-05 \varepsilon t^{-2.227}$ & 5423 & 3982 & 2145 & 1210 \\
\hline
\end{tabular}

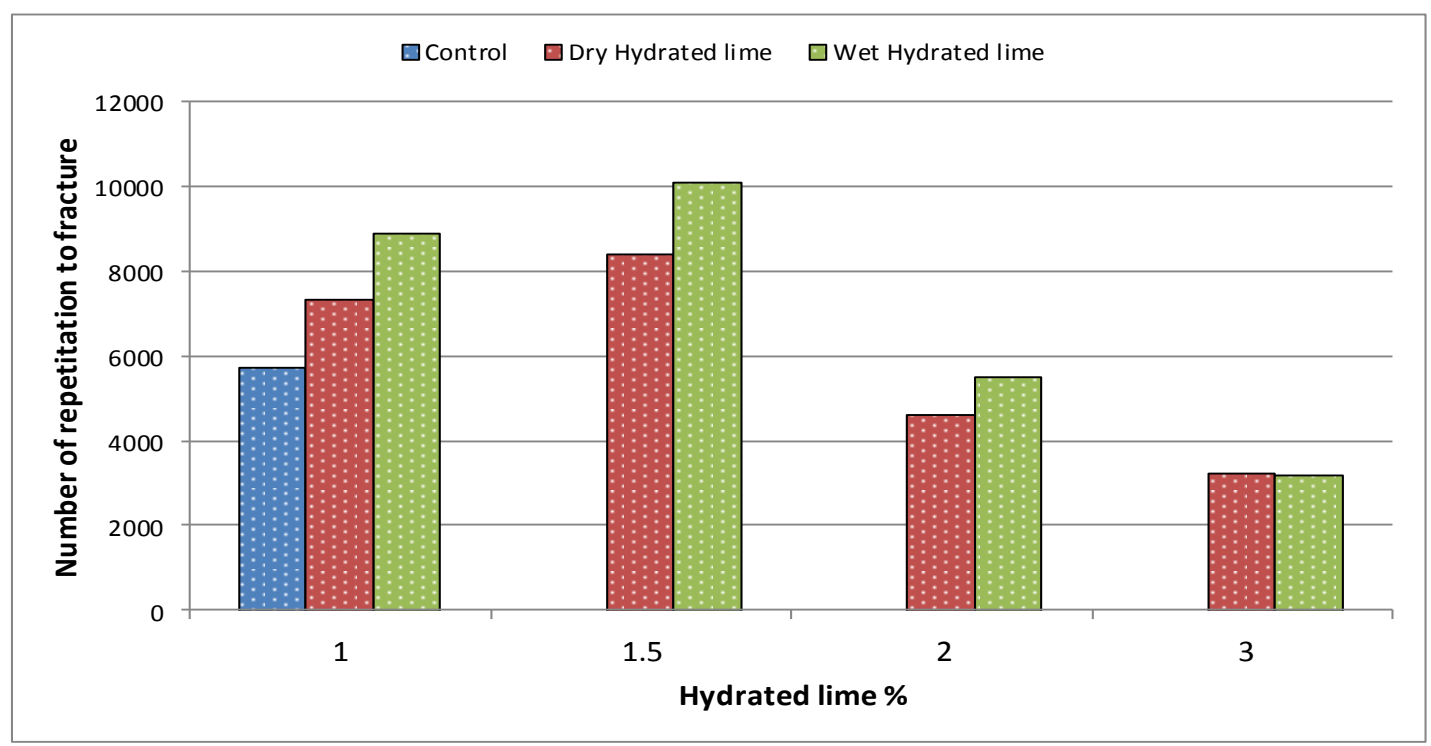

Figure 12. Average fatigue life

\section{PERFORMANCE ANALYSIS USING VESYS 5W SOFTWARE}

Using vesys $5 \mathrm{w}$ software to analyze a pavement section consisting of a $150 \mathrm{~mm}$ asphalt concrete layer over a $400 \mathrm{~mm}$ base course layer with 1.0 million ESALs application during 10 years' service life, the present serviceability index trend line is abstracted from the output results of the software and is shown in Figure 10. The figure clearly shows that the pavement section which consists of asphalt concrete layer modified with 1.5 percent 
lime (wet application method) provided better performance as compared to the mixes with 1.5 percent lime (dry application method) or the mix with 0 lime. The PSI values at the end of 10 years' service life are 3.01, 2.8 and 2.64 for the pavement sections with bituminous concrete layers containing 1.5 percent lime (wet), 1.5 percent lime (dry) and 0 lime, respectively. The PSI values in vesys $5 \mathrm{w}$ software reflect the effect of rutting and cracking for a pavement section during the design life.

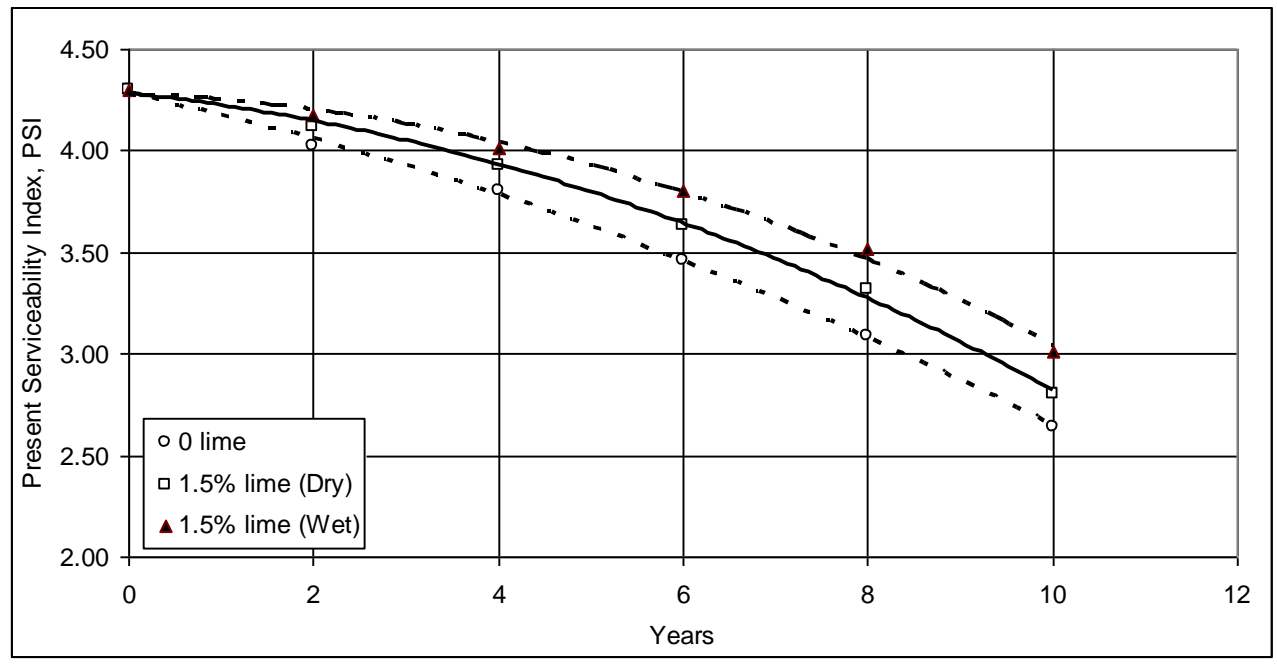

Figure 13. Performance analysis for mixes modified with 1.5 percent lime with two addition methods

\section{CONCLUSIONS}

The following conclusions and recommendations are based on the results of the laboratory tests and analysis presented in this study:

- The use of both hydrated lime addition methods exhibited a good resistance against moisture damage, with an increase in TSR of 4.2\%, 5.3\%, 5.9\% 10.9\%, and $9.0 \%$ for the dry hydrated lime replacement method and 3.4\%, 6\%, 18.8\%, ???, 19.8\% for the wet hydrated lime replacement method corresponding to 1.0, 1.5, 2.0 and 3.0 lime contents, respectively. This indicates that the wet addition method was more effective than the dry method in improving the resistance to moisture induced damage of bituminous concrete pavement modified with hydrated lime

- The permanent deformation parameters slope and intercept, were significantly affected using dry and wet hydrated lime addition methods employing different percentages of hydrated lime and this effect is more pronounced at high testing temperatures. The lime modified mix with 1.5 percent using the dry method and 2 percent using the wet method resulted in a decrease in permanent deformation slope value of 9.4 and 10.1 percent, respectively, at a temperature of $40^{\circ} \mathrm{C}$ as compared to the control mixture with no hydrated lime. 
- The dry addition method of hydrated lime as a filler substitute results in better elastic modulus as characterized by the resilient modulus test in comparison with the wet addition method. The use of 3 percent lime, respectively at $20^{\circ} \mathrm{C}, 40^{\circ} \mathrm{C}$ and $60^{\circ} \mathrm{C}$ test temperature improved the resilient modulus by $40.2,35.2$ and 25.4 percent with the dry addition method whereas for the wet addition method the corresponding values were 29.1, 23.8 and 10.8 percent as compared to control mixes with no hydrated lime.

- For both addition methods, the use of 1.5 percent hydrated lime as a filler substitute improved the fatigue property of the bituminous concrete mixes as determined by the flexural test. The $k_{2}$ value (inverse slope of fatigue line) for mixes with 1.5 percent hydrated lime in both dry and wet addition methods was more than that of 0 percent hydrated lime by 43.8 and 49.3 percent, respectively.

- The use of 1.5 percent hydrated lime in the wet addition method as replacement for limestone dust mineral filler has shown a significant improvement of bituminous concrete behavior and has added to local knowledge the possibility of producing more durable mixtures with higher resistance to distress.

\section{REFERENCES}

AASHTO, (2004) "Evaluation of Superpave Gyratory Compactors (SGC's)", AASHTO Designation: PP-35, American Association of State Highways and Transportation Officials, Washington, D.C.

Albayati A.,H , Alani A,M., (2012), "Laboratory investigation in the Hydrated Lime effect on asphalt concrete mixture", preceding of The First National Conference for Engineering Sciences FNCES'12, Baghdad, Iraq.

Albayati, A.H., (2006),"Permanent Deformation Prediction of Asphalt Concrete Under Repeated Loading" Ph.D. Thesis, Baghdad University.

Albayati,A. H.,(2012)," Mechanistic Evaluation of Lime-Modified Asphalt Concrete Mixtures", $7^{\text {th }}$ RILEM International Conference on Cracking in Pavements RILEM Book series, 2012, Volume 4, PP .921-940.

AlSuhaibani, A. R., Al-Mudaiheem, J., and Al-Fozan ,F.(1992), " Effect of Filler Type and Content on Properties of Asphalt Concrete Mixes". In Effects of Aggregates and Mineral Fillers on Asphalt Mixtures Performance, SPT 1147 (R. C. Meininger, ed.), ASTM, Philadelphia, Pa., pp. 107-130.

Barksdale, R.,( 1971), "Compressive stress Pulse Times in flexible pavements for use in dynamic Testing”, No.345 , pp 32-44 ,Highway Research Record.

Button, J.W., and Epps, J.A. (1983)." Evaluation of methods of mixing lime and asphalt paving mixtures". Texas Hot Asphalt Pavement Association.

European Lime Association / Asphalt Task Force,(2011), “ Hydrated lime a Proven additives for Durable asphalt Pavement.

Hicks, R. G. (1991),:" Moisture Damage in Asphalt Concrete", NCHRP Synthesis of Highway Practice 175,TRB, National Research Council, Washington, D.C. 
Huang, Y. H., (2004), "Pavement Analysis and Design “, 2nd edition , Pearson Prentice Hall , Pearson Education, Inc . ,Upper Saddle River, NJ 07458.

Huang, S.-C., J. C. Peterson, R. E. Robertson, and J. F. Branthaver.,(2002) "Effect of Hydrated Lime on Long-Term Oxidative Aging Characteristics of Asphalt". In Transportation Research Record: Journal of the Transportation Research Board, No. 1810, Transportation Research Board of the National Academies, Washington, D.C., pp. $17-24$.

Hydrated Lime (2003) "More Than Just a Filler". National Lime Association, www.lime.org/HydratedLime.pdf.

Kennedy, T. W., and Ping, W. V.(1991)," An Evaluation of Effectiveness of Antistripping Additives in Protecting Asphalt Mixtures from Moisture Damage", Presented at Annual Meeting of the Association of Asphalt Paving Technologies.

Little, D, and Epps, J. (2001),." The Benefits of Hydrated Lime in Hot Mix Asphalt". National Lime Association,. www.lime.org/ABenefit.pdf.

Little, D.N. and Petersen, J.C. (2005). "Unique Effects of Hydrated Lime Filler on the Performance- Related Properties of Asphalt Cements: Physical and Chemical Interactions Revisited." Journal of Materials in Civil Engineering, Volume 17, No. 2, pp.207-218.

Mohammad, L. N., Abadie, C., Gokmen ,R., and Puppala, A. J.,(2000) ,’Mechanistic Evaluation of Hydrated Lime in Hot-Mix Asphalt Mixtures". In Transportation Research Record: Journal of the Transportation Research Board, No. 1723, TRB, National Research Council, Washington, D.C.,pp. 26-36.

Monismith, C., Ogawa, N. and Freeme, C. (1975). "Permanent Deformation Characteristics of Subgrade Soils due to Repeated Loadings", TRR 537.

Plancher, H., S. Dorrence, and J. C. Petersen. 1977." Identification of Chemical Types in Asphalts Strongly Absorbed at the Asphalt-Aggregate Interface and Their Relative Displacement by Water". Proc., Association of Asphalt Paving Technologists, Vol. 46, pp. $151-175$.

SCRB/R9 (2003). "General Specification for Roads and Bridges", Section R/9, Hot-Mix Asphalt Concrete Pavement, Revised Edition. State Corporation of Roads and Bridges, Ministry of Housing and Construction, Republic of Iraq.

Sebaaly, P.E., Hitti, E. and Weitzel, D. 2003. "Effectiveness of Lime in Hot Mix Asphalt Pavements." Transportation Research Record: Journal of the Transportation Research Board, No. 1832, Transportation Research Board of the National Academies, Washington, D.C.

Sebaaly, P. E., (2006)," The Benefits of Hydrated Lime in Hot Mix Asphalt", National Lime Association.

Shahrour, M. A., and Saloukeh, B. G.(1992)." Effect of Quality and Quantity of Locally Produced Filler (Passing Sieve No. 200) on Asphaltic Mixtures in Dubai". In Effects of Aggregates and Mineral Fillers on Asphalt Mixtures Performance, SPT 1147 (R. C. Meininger, ed.), ASTM, Philadelphia, Pa., pp. 187-208. 